\title{
DIVERSIFIKASI PEPAYA PADA BIDANG PANGAN DAN KEPERAWATAN DI DESA RIDAN PERMAI KECAMATAN BANGKINANG KOTA
}

\author{
Yenny Safitri, M.Kep ${ }^{1}$, Dewi Sulastri Juwita, M.Kep ${ }^{2}$, Nany Librianti, SE., MMA ${ }^{3}$ \\ ${ }^{1}$ Porgram Studi Profesi Ners, Fakultas Ilmu Kesehatan, Universitas Pahlawan Tuanku Tambusai \\ e-mail : yennysafitri37@yahoo.co.id \\ ${ }^{2}$ Program Studi Sarjana Keperawatan, Fakultas Ilmu Kesehatan, Universitas Pahlawan Tuanku Tambusai \\ e-mail: dewisulastri@gmail.com \\ ${ }^{3}$ Program Studi Sarjana Keperawatan, Fakultas Ilmu Kesehatan, Universitas Pahlawan Tuanku Tambusai \\ e-mail : nanylibrianti@rocketmail.com
}

\begin{abstract}
Abstrak
Buah pepaya tidak hanya bisa diolah menjadi produksi industri rumah tangga (makanan) namun bisa dimanfaatkan untuk masyarakat luas seperti di bidang kesehatan, khususnya Keperawatan.Berdasarkan survey lapangan yang penulis lakukan langsung ke Desa Ridan Permai, didapatkan data dan informaasi bahwa mereka tidak mengetahui manfaat keseluruhan dari buah pepaya, bagaimana cara mengolah pepaya agar berdaya guna dibidang pangan dan keperawatan, bernilai jual tinggi dan mampu membuka lapangan kerja. Hasil wawancara penulis dengan petani pepaya di Desa Ridan Permai bahwa buah pepaya hanya dijual ke pengepul dan mendapatkan uang Rp. $\pm 2.000,-/ \mathrm{kg} / \mathrm{bh}$. Hal ini dikarenakan petani takut pepaya akan berjamur sehingga harga makin anjlok akan merugikan petani pepaya. Berdasarkan analisis situasi ternyata pengolahan komoditi pepaya belum ada dilakukan oleh masyarakat di kecamatan Bangkinang. Hal ini dikarenakan keterbatasan informasi, sarana dan prasarana dalam penggolahan bahan berbaku pepaya. Tahapan -tahapan pelaksanaan kegiatan pengabdian ini antara lain ; Penyuluhan, Pelatihan, Uji coba, Monitoring dan Evaluasi, dan Partisipasi Mitra. Mitra sangat antusias terhadap sosialisasi serta pelatihan yang telah dilakukan dalam peningkatan produksi pengolahan pepaya berupa variasi produk baru hasil olahan pepaya yaitu; keripik pepaya, keripik daun pepaya, manisan pepaya, dan jus papaya. Hasil penelitian ini didapatkan data mitra antusia tentang pengolahan pepaya menjadi varian produk lain, mitra antusias memperhatikan cara pembuatan pembukuan sederhana yang diperlukan untuk pengembangan usaha selanjutnya dan mitra antusia mempelajari tentang cara olahan pepaya menjadi obat sebagai terapi komplementer yang bisa digunakan untuk mengobati berbagai penyakit dimasyarakat
\end{abstract}

Kata kunci: Diversifikasi, Buah Pepaya

\begin{abstract}
Papaya fruit not only can be processed into industrial production household (food) but can be used for the wider community such as in the health field, especially Nursing.Based on the field survey that the author did directly to the Village Ridan Permai, data obtained and informaasi that they did not know the overall benefits of papaya fruit, how to cultivate papaya so efficient in the field of food and nursing, high value and capable of open employment. The results of the interview of the author with the papaya farmers in the Village Ridan Permai that the papaya fruit is only sold to collectors and get the money of Rp. $\pm 2.000,-/ \mathrm{kg} / \mathrm{bh}$. This is because the farmers are afraid of the papaya will be moldy so the price is getting dropped will hurt the papaya farmers. Based on the analysis of the situation it turns out that the processing of the commodity papaya has not been done by the community in the district of Bangkinang. This is due to the limited information, facilities and infrastructure in the treatment material berbaku papaya. The implementation stages of the activities of this devotion among others ; Counseling, Training, Testing, Monitoring and Evaluation, and Partner Participation. Partners are very enthusiastic about the socialization and training that has been done in the improvement of the production processing of papaya in the form of variations of new products the results of the processed papaya namely; papaya chips, chips papaya leaves, candied papaya, and the juice of papaya. The results of this study obtained data partners antusia about the processing of papaya to be a variant of another product, partners enthusiastically paying attention to ways of making a simple bookkeeping
\end{abstract}


required for business development and partner antusia learn about how processed papaya into medicine as a complementary therapy that can be used to treat a variety of diseases in the community

Keywords : Diversification, Papaya Fruit

\section{PENDAHULUAN}

Salah satu daerah penghasil buah pepaya terbesar di Kabupaten Kampar setelah Siak Hulu adalah Bangkinang. Daerah Bangkinang terdiri 4 kelurahan/Desa yang terdiri dari kelurahan Bangkinang Kota, Desa Kumantan, Desa Ridan Permai dan Kelurahan Langgini. Kelurahan Ridan Permai terdiri dari dusun I, II, dan III dengan jumlah penduduk 3.768 jiwa dan kepala keluarga (KK) lebih kurang 1.200 jiwa. Pada dusun I dan II lahan pepaya sudah dipergunakan untuk perumnas dengan jumlah penduduk 1578 jiwa. Sektor perkebunan pepaya merupakan sektor unggulan di desa ini terutama di dusun III, disampingsebagai pekerja bangunan, pedagang dan berkebun sayuran. Luas perkebunan pepaya didesa ini \pm 20 hektar. Perkebunan pepaya ini telah memberikan manfaat finansial bagi penduduk setempat. Berdasarkan hasil informasi lapangan dan observasi sementara, hampir 95\% petani pepaya cenderung berpikir praktis dengan hanya menjual buah pepaya langsung ke pengepul dengan harga perkilo hanya $\mathrm{Rp} \pm 3.000,-/ \mathrm{kg} / \mathrm{bh}$.

Berdasarkan survey lapangan yang penulis lakukan langsung ke Desa Ridan Permai, didapatkan data dan informaasi bahwa mereka tidak mengetahui manfaat keseluruhan dari buah pepaya, bagaimana cara mengolah pepaya agar berdaya guna dibidang pangan dan keperawatan, bernilai jual tinggi dan mampu membuka lapangan kerja. Hasil wawancara penulis dengan petani pepaya di Desa Ridan Permai bahwa buah pepaya hanya dijual ke pengepul dan mendapatkan uang Rp. $\pm 2.000,-/ \mathrm{kg} / \mathrm{bh}$. Hal ini dikarenakan petani takut pepaya akan berjamur sehingga harga makin anjlok akan merugikan petani pepaya. Untuk mengantisipasi kondisi ini ini ada beberapa orang petani membuka usaha sampingan seperti buka kedai/warung kopi. Hal ini juga didukung denga tingkat ekonomi masyarakat ridan permai berada dalam kategori menengah kebawah.

Berdasarkan analisis situasi ternyata pengolahan komoditi pepaya belum ada dilakukan oleh masyarakat di kecamatan Bangkinang. Hal ini dikarenakan keterbatasan informasi, sarana dan prasarana dalam penggolahan bahan berbaku pepaya. Saat ini, di kecamatan Bangkinang di desa Ridan Permai hanya ada penggolahan dan diversifikasi susu kambing menjadi sabun mandi, sabun cuci piring, dan susu kambing etawa yang lakukan oleh Bapak Erwin meskipun usaha yang dikembangkan oleh beliau belum secara maksimal membuka peluang kerja untuk masyarakat setempat. Pepaya bisa diolah menjadi makanan panganan makanan,dan bisa diolah menjadi obat tradisonal yang bisa dimanfaatkan masyarakat untuk mengatasi berbagai masalah kesehatan seperti : kesehatan kulit, membesarkan alat kelamin pria, mengoptimalkan alat pencernaan, meminimalisir risiko mata rusak, menagngkal radikal bebas, obat bekas gigitan ular berbisa, obat kulit melepuh, obat demam atau malaria, obat flu, obat sakit gigi. Namun hal ini belum bisa diwujudkan karena keterbatasan dana, pengetahuan, keterampilan, alat untuk pengolahan dan cara pendistribusian hasil produksi. Namun masyarakat yang berdomisili di desa Ridan Permai hanya memiliki pengetahuan bahwa pepaya hanya bermanfaat atau dapat dijual dari aspek buahnya saja. Ketika dilakukan tinjaun ke desa Ridan Permai dan berkomunikasi dengan petani pepaya dapat di lihat bahwa mereka berpotensi untuk menjadi sumberdaya manusia profesional dalam pengolahan pepaya menjadi produk olahan industri rumah tangga, bisa berupa produk makanan yang dapat dikonsumsi, yang bila dibantu dan diajak bekerjasama diharapkan ke depannya dapat mengarahkan penduduk sekitar yang awam terhadap cara pengolahan pepaya ini dapat memperoleh keterampilan dan pengetahuan yang dapat membantu mereka untuk meningkatkan taraf perekonomian. Belum adanya pedoman panduan kegiatan usaha tani dari dinas dan minimnya penguasaan tentang manajemen pemasaran.

Berdasarkan hasil pengamatan, para petani masih bersifat konvensional. Dari kondisi ini menunjukkan bahwa potret masyarakatmasih kurang memiliki kompetensi dalam mengolah pepaya. Hal ini dapat dinilai dari sikap dan perilaku penduduk yang mensia-siakan peluang usaha yang sudah sepantasnya mereka berdayakan. Dengan kegiatan pembinaan dan penyuluhan berupa keterampilan dan pengetahuan pembudidayaan dari pihak yang berkompeten diharapkan dapat 
menambah pemasukan dari sektor finansial warga masyarakat setempat yang akhirnya akan meningkatkan kesejahteraan mereka. Untuk menunjang keberlangsungan kegiatan produksi dan pemasaran, kelompok tani pepaya dipandang perlu menyusun marketing programme sebagai cara untuk media publikasi ke masyarakat luas.

\section{METODE}

Solusi yang ditawarkan kepada mitra untuk mengatasi permasalahan mitra adalah sebagai berikut : melakukan aplikasi kapasitas Ipteks dalam sistem produksi, Peningkatan Kualitas Dan Kuantitas Hasil Produksi Rumah Tangga Berbahan Baku Pepaya Metoda pelaksanaan yang dilakukan agar solusi yang ditawarkan dapat disalurkan dengan baik kepada mitra sesuai yang diharapkan maka upaya yang dilakukan adalah dengan memberikan penyuluhan dan pelatihan kepada mitra petani pepaya. Tahapan -tahapan pelaksanaan kegiatan pengabdian ini antara lain:

1. Penyuluhan

2. Pelatihan

3. Uji coba

4. Monitoring dan Evaluasi

5. Partisipasi Mitra

\section{HASIL DAN PEMBAHASAN}

\section{Hasil Kegiatan}

Hasil kegiatan pengabdian masyarakat yang dicapai sebagai berikut:

a. Antusias mitra terhadap sosialisasi serta pelatihan yang telah dilakukan dalam peningkatan produksi pengolahan pepaya berupa variasi produk baru hasil olahan pepaya yaitu; keripik pepaya, keripik daun pepaya, manisan pepaya, dan jus papaya

b. Meningkatkan pengetahuan dan keterampilan mitra tentang pengolahan pepaya menjadi varian produk lain

c. Meningkatkan pengetahuan mitra tentang cara pembuatan pembukuan sederhana yang diperlukan untuk pengembangan usaha selanjutnya

d. Meningkatkan pengetahuan mitra tentang cara olahan pepaya menjadi obat sebagai terapi komplementer yang bisa digunakan untuk mengobati berbagai penyakit dimasyarakat

e. Materi sosialisasi pembuatan keripik pepaya, keripik daun pepaya, manisan pepaya, dan jus papaya yang terlampir pada lampiran

f. Materi sosialisasi pengobatan tradisional berbahan baku pepaya terlampir

g. Dokumentasi foto pada setiap kegiatan pengabdian masyarakat terlampir

\section{Materi pada sosialisasi/penyuluhan}

Materi yang disampaikan dalam kegiatan ini, meliputi:

a. Pentingnya pemilihan pepaya dengan kualitas yang baik guna menghasilkan produk olahan yang baik

b. Cara penggunaan alat yang digunakan dalam kegiatan produksi olahan papaya

c. Bahan bahan yang digunakan dan cara pembuatan produk olahan pepaya menjadi varian lain diantaranya; keripik pepaya, keripik daun pepaya, manisan pepaya, dan jus papaya

d. Cara membuat pembukuan sederhana terkait tentang arus kas

e. Cara pengolahan pepaya menjadi obat komplementer

\section{Persiapan Pelatihan Produk olahan pepaya keripik pepaya, manisan pepaya,dan jus papaya )}

Dalam proses pembuatan produk olahan pepaya, maka diperlukan persiapan yang baik sehingga bisa mempermudah proses pembuatan produk. Hal terkait dalam persiapan meliputi:

a. Penentuan Materi 
Materi yang akan diajarkan kepada mitra yaitu bagaimana cara pembuatan produk olahan pepaya (pembuatan keripik pepaya, keripik daun pepaya, manisan pepaya, jus pepaya)

b. Persiapan perlengkapan pelatihan

Mempersiapkan perlengkapan alat-alat dan bahan-bahan yang digunakan dalam pelatihan pembuatan produk olahan pepaya.

c. Tempat Pelatihan

Tempat pelatihan dilakukan di kantor desa Ridan Permai ini menjadi pilihan tempat kegiatan karena mudah diakses oleh seluruh anggota mitra.

\section{Persiapan Pelatihan pembukuan sederhana}

a. Penentuan Materi

Materi yang diajarkan kepada mitra yaitu cara membuat pembukuan sederhana, tentang arus kas uang masuk dan uang keluar

b. Persiapan Perlengkapan Pelatihan

Mempersiapkan perlengkapan alat-alat yang digunakan dalam pelatihan pembukuan sederhana

c. Tempat Pelatihan

Tempat pelatihan dilakukan di kantor desa Ridan Permai. Tempat ini karena menjadi pilihan tempat kegiatan karena mudah diakses oleh seluruh anggota mitra.

\section{Persiapan Pelatihan Pengobatan Tradisional}

a. Penentuan Materi

Materi yang diajarkan kepada mitra yaitu cara membuat pengobatan tradisional berbahan baku pepaya

b. Persiapan Perlengkapan Pelatihan

Mempersiapkan perlengkapan alat-alat yang digunakan dalam pelatihan pengobatan tradisional berbahan baku pepaya

c. Tempat Pelatihan

Tempat pelatihan dilakukan di kantor desa Ridan Permai. Tempat ini menjadi pilihan tempat kegiatan karena mudah diakses oleh seluruh anggota

\section{SIMPULAN}

a. Mitra sangat antusias terhadap sosialisasi serta pelatihan yang telah dilakukan dalam peningkatan produksi pengolahan pepaya berupa variasi produk baru hasil olahan pepaya yaitu; keripik pepaya, keripik daun pepaya, manisan pepaya, dan jus papaya

b. Mitra antusia tentang pengolahan pepaya menjadi varian produk lain

c. Mitra antusias memperhatikan cara pembuatan pembukuan sederhana yang diperlukan untuk pengembangan usaha selanjutnya

d. Mitra antusia mempelajari tentang cara olahan pepaya menjadi obat sebagai terapi komplementer yang bisa digunakan untuk mengobati berbagai penyakit dimasyarakat

\section{SARAN}

Diharapkan kedepannya pengabdian masyarakat ini tidak hanya dilakukan diversifikasi pada olahan makanan saja tapi juga untuk komoditas usaha lainnyaberbahan baku pepaya dan bisa dijual ke Luar Negeri

\section{UCAPAN TERIMA KASIH}

Penulis mengucapkan terimaksih kepada Universitas Pahlawan Tuanku Tambusai yuang telah memberikan dukungan finansial kegiatan pengabdian masyarakat ini. 


\section{DAFTAR PUSTAKA}

Anonim ( http://aplimugiwara23.blogspot.co.id/2015/01/makalah-pepaya.html)

Anonim (http://kamuslife.com/2012/04/jenis-jenis-kegiatan-dalam-industri-pangan.html)

Indriyani, S. (2004). Kewirausahaan konsep dan realita pada usaha kecil.

http://www.pengolahannanas.com

Sukirno (2013). Peningkatan kemampuan teknologi olahan pangan berbasis sumber daya lokal buah nanas (ananas comosus l merr) di kabupaten Subang. Balai Besar Pengembangan

Teknologi tepat guna-LIPI. Subang

Suparyanto (2012). Kewirausahaan Konsep dan Realita pada usaha kecil. Bandung:

Alfabeta

Rukmana, R (2007) . Budidaya Melon Hibrida. Kanisius 